\title{
EFEKTIVITAS PEMBELAJARAN MENGANALISIS CERITA PENDEK MENGGUNAKAN MODEL DISCOVERY LEARNING
}

\author{
Dirwan \\ SMA Pasundan I Cianjur 43216 \\ dirwandarmawangsa123@gmail.com
}

\begin{abstract}
This article discusses the effectiveness of students' learning, interests, and abilities in analyzing characters and characterizing short stories using the discovery learning model. The method used is classroom action research with 3 cycles, with instrument in the form of observation sheet and questionnaire. The research was conducted in class XI SMA Pasundan I Cianjur. The results of the study showed that there was an increase in the effectiveness of learning. In the first cycle of class is still noisy, then on the second cycle has started not rowdy, and on the III cycle is good. Student interest also increases in cycle I students who are active only a small part, on the second cycle began to grow and in cycle III is already high. Students' ability in analyzing short story also increases because in cycle I the average score of students is only 69,58, at second cycle of 81,66 and in cycle III reach 85,20. It was concluded that the use of discovery learning model in learning to analyze character and characterization in class XI SMA Pasundan 1 Cianjur can improve the effectiveness, student interest and student learning outcomes.
\end{abstract}

Keywords: short story, discovery learning.

\section{PENDAHULUAN}

Materi ajar dalam bahasa dan sastra Indonesia ada dua rumpun ilmu, yaitu bahasa dan sastra. Sastra tidak dapat dipisahkan dari struktur atau unsur pembangunnya, karena sastra merupakan cabang ilmu yang ditelaah oleh manusia, baik dari segi struktur pembangun maupun makna karya sastra tersebut. Sastra sebagai ungkapan pribadi manusia yang berupa pengalaman, pemikiran, perasaan, ide, semangat, dan keyakinan dalam suatu bentuk gambaran kongkret yang menggunakan bahasa sebagai perantaranya yang dapat membangkitkan berbagai pesona kepada kita sebagai penikmatnya. Sastra juga mempunyai unsur-unsur pembentuk di dalamnya yang memiliki arti bila kita ketahui dan dikaji secara teliti.

Mengingat perlunya ilmu sastra, terutama pemahaman melalui menganalisis akan bermanfaat bagi perkembangan ilmu kesusastraan di dunia pendidikan. Pembelajaran sastra dalam pendidikan formal perlu dikembangkan dan dilestarikan dari apa yang sudah ada sekarang ini. Pembelajaran sastra di lembaga pendidikan formal, pada dasarnya adalah suatu pembelajaran yang bertujuan untuk memperkenalkan dan memberikan pemahaman mengenai makna yang terkandung dalam karya sastra kepada siswa dan mengajak siswa untuk menghargai atau berapresiasi terhadap pengalaman-pengalaman yang terkandung di dalamnya.

Karya sastra memiliki beberapa jenis di antaranya puisi, prosa, dan drama. Di dalam prosa salah satunya adalah cerita pendek dan memiliki jenis atau keinginan yang hampir sama dengan jenis karya sastra lainnya yakni berkomunikasi, menyampaikan pesan melalui tulisan baik dari hasil khayalan maupun realita kehidupan, seperti yang dikutip di bawah ini. 
Tarigan (1994: 138), mengatakan bahwa cerpen merupakan cerita rekaan yang masalahnya jelas, singkat, dan terkonsentrasi pada satu peristiwa. Cerpen sebagai salah satu karya sastra yang diangkat dari kehidupan nyata atau kehidupan sehari-hari, dengan sikap/watak yang diciptakan, kemudian tempat kejadian/pristiwa yang ditampilkan serta amanat yang disampaikan oleh setiap pengarang.

Berdasarkan hasil observasi di sekolah, khususnya dalam pembelajaran bahasa dan sastra Indonesia, bahwa pengajaran sastra terkesan terpinggirkan, misalnya ada yang memposisikan sastra sebagai hiburan. Di sekolah-sekolah pun sastra dianggap sebagai pelengkap pelajaran bahasa, bahkan fenomena saat ini porsi sastra lebih dikurangi dalam pembelajaran bahasa dan sastra di sekolah. Sering jam pelajaran sastra digantikan oleh pelajaran tatabahasa. Cara pengajaran sastra monoton. Guru sastra banyak yang kurang memahami sastra, sehingga tidak menggiring siswa untuk lebih mengenal sastra. Akibatnya tingkat apresiasi siswa terhadap sastra semakin menurun.

Salah satu contoh kongkret yang dapat dilihat adalah menurunnya tingkat apresiasi siswa terhadap sastra khususnya cerita pendek. Siswa disuruh membaca cerpen tampak malas, tidak bersemangat, bahkan ada yang tiduran. Apalagi dalam hal menganalisis, keadaan kelas tidak kondusif, kelas gaduh, malah lebih senang bermain gawai (handphon), padahal dalam kurikulum 2013 tercantum di Kompetensi Dasar untuk menganalisis cerita pendek. Saat ini, siswa hanya mengetahui mengenai cerita pendek, seperti cerita jalan-jalan ke rumah nenek dan sebagainya, tanpa mengenal dan mempelajarinya lebih dalam. Sedangkan pemahaman terhadap struktur yang terkandung dalam cerita pendek sama sekali tidak dihiraukan. Padahal itu berguna bagi siswa, karena dalam cerita pendek terdapat strukturstruktur pembangun yang akan menjembatani pada pemahaman di dalam cerita pendek tersebut.
Dilihat dari permasalahan di atas, discovery learning merupakan model yang bisa mendapatkan gambaran peningkatan efektivitas dalam pembelajaran, minatnya dalam mengapresiasi sastra, serta hasil yang memuaskan dalam proses pembelajaran sastra khususnya cerita pendek. Seperti yang dikemukakan oleh Hosnan (2014: 282), Pembelajaran discovery learning adalah suatu model untuk mengembangkan cara belajar siswa aktif untuk menemukan sendiri, menyelidiki sendiri, maka hasil yang diperoleh akan setia dan tahan lama dalam ingatan, tidak akan mudah dilupakan siswa. Dengan belajar penemuan, anak juga bisa berpikir analisis dan mencoba memecahkan sendiri problem yang dihadapi. Kebiasaan ini akan ditransfer dalam kehidupan bermasyarakat. Maka discovery learning merupakan model baru yang akan memberikan nuansa berbeda dalam proses pembelajaran yang semula pembelajaran sastra monoton, karena guru yang lebih banyak aktif, tapi discovery learning, siswalah yang akan berperan lebih aktif sehingga akan menimbulkan apresiasi sastra pada siswa meningkat, sebab mereka yang akan mencari dari berbagai sumber.

Artikel ini dimaksudkan untuk memaparkan kemampuan siswa dalam pembelajaran sastra dengan cara menganalisis tokoh dan penokohan. Pentingnya menganalisis tokoh dan penokohan sebab mutu sebuah cerpen banyak ditentukan oleh kepandaian penulis yang menghidupkan tokohnya, jika tokoh lemah maka lemah pula jalan ceritanya. Dalam tokoh (watak tokoh) banyak nilai-nilai kehidupan yang dapat diserap oleh pembaca. Seperti yang dikemukakan oleh Ristiani (2012: 94), tokoh dapat ditinjau dari segi keterlibatannya dalam keseluruhan cerita (tokoh sentral dan tokoh tambahan) dan dilihat dari fungsi dan penampilan tokoh (tokoh protagonis dan tokoh antagonis) dalam cerita pendek dengan menggunakan model pembelajaran discovery learning.

\section{METODE PENELITIAN}


Metode yang digunakan dalam penelitian adalah metode Penelitian Tindakan Kelas (PTK). Penelitian Tindakan Kelas (PTK) merupakan suatu penelitian yang dilakukan oleh guru di dalam kelasnya sendiri melalui refleksi diri dengan tujuan untuk memperbaiki kinerja sebagai guru, agar tujuan dari pembelajaran tersebut dapat tercapai. Menurut Arikunto dkk. (2012: 16) penelitian tindakan kelas ini terdiri dari empat komponen, yakni perencanaan, pelaksanaan, pengamatan (observasi) dan refleksi.

Adapun penelitian yang dilaksanakan oleh peneliti terdiri dari tiga siklus yang tiap siklusnya satu pertemuan. Penelitian dilaksanakan selama dua bulan, yaitu bulan Oktober-November 2016 pada siswa kelas XI IPS 2 SMA Pasundan 1 Cianjur.

Bentuk instrumen yang digunakan dalam penelitian adalah tes siklus, lembar observasi guru dan siswa serta angket kemudian mempersiapkan silabus dan Rencana Pelaksanaan Pembelajaran (RPP) yang disesuaikan dengan sekolah tersebut.

\section{HASIL PENELITIAN}

\section{Efektivitas Pembelajaran}

Keefektifan pembelajaran pada pembelajaran siklus I dengan penyajian materi menganalisis cerpen "Seragam" karya A. K. Basuki menggunakan model pembelajaran discovery learning dengan menggunakan internet di blog: http://dirwandarmawangsa. blogspot.co.id/ pada siswa SMA Pasundan 1 Cianjur kelas XI IPS 2, belum diperoleh hasil yang maksimal karena keadaan kelas masih kurang kondusip, dari jumlah kesuluruhan siswa 24 yang memperhatikan dan fokus pada pembelajaran sebanyak 12 siswa $(50 \%)$.

Keefektifan pembelajaran pada pembelajaran siklus II dengan penyajian materi menganalisis cerpen "Guru (1)" karya Putu Wijaya menggunakan model pembelajaran discovery learning dengan menggunakan metode pembacaan cerpen dalam vidio pada siswa SMA Pasundan 1 Cianjur kelas XI IPS
2, belum diperoleh hasil yang maksimal, tapi sudah ada peningkatan dibandingkan dengan siklus I, karena pada siklus II dari jumlah kesuluruhan siswa 24 yang memperhatikan dan fokus pada pembelajaran sebanyak 19 siswa $(79,04 \%)$.

Keefektifan pembelajaran pada pembelajaran siklus III dengan penyajian materi menganalisis cerpen "Menanti Kematian" karya Jujur Prananto menggunakan model pembelajaran discovery learning dengan menggunakan metode mencari ruangan baru dan nyaman pada siswa SMA Pasundan 1 Cianjur kelas XI IPS 2, sudah diperoleh hasil yang maksimal dibandingkan dengan siklus I dan II, karena pada siklus III dari jumlah kesuluruhan siswa 24 yang memperhatikan dan fokus pada pembelajaran sebanyak 22 siswa $(91,52 \%)$.

Dari deskripsi keadaan kelas di atas dapat disimpulkan dari setiap siklusnya keefektifan pembelajaran ada peningkatan positif, dari siklus I ke siklus II dan ke siklus III jumlah siswa yang memperhatikan dan fokus pada pembelajaran siklus I 12 siswa (50\%), siklus II 19 siswa $(79,04 \%)$, dan siklus III 22 siswa (91,52\%). Hal itu membuktikan bahwa model pembelajaran discovery learning dengan menggunakan metode yang berbeda pada setiap siklusnya dalam pembelajaran menganalisis cerpen dapat meningkatkan keadaan siswa menjadi memperhatikan dan fokus sehingga menjadi kondusif.

Hal itu sesuai dengan apa yang diungkapkan oleh Budiarty (2015: 175), bahwa model discovery learning yang diterapkan pada siswa SMP Negeri 2 Cianjur kelas VIII-2 dalam pembelajaran menyimak teks biografi dapat meningkatkan keefektifan pembelajaran, terbukti setiap siklusnya mengalami peningkatan dilihat dari lembar observasi peserta didik.

\section{Minat Siswa dalam Pembelajaran}

Minat siswa pada pembelajaran siklus I dengan penyajian materi menganalisis cerpen 
"Seragam" karya A.K.Basuki menggunakan model pembelajaran discovery learning dengan menggunakan metode internet di blog: http://dirwandarmawangsa.blogspot.co. id/ pada siswa SMA Pasundan 1 Cianjur kelas XI IPS 2, masih rendah karena dari jumlah kesuluruhan 24 siswa yang fokus membaca teks cerpen tanpa terganggu oleh temannya sebanyak 10 siswa $(41,6 \%)$.

Berdasarkan deskripsi di atas ternyata pembelajaran siklus I di dalam minat siswa sangat rendah. Untuk menyalesaikan permasalahan tersebut peneliti memperbaiki pada siklus II dengan mengacu pada teori menurut Aqib (2007: 108), bahwa permasalahan di dalam penelitian tindakan kelas harus diselesaikan secara kolaboratif untuk memecahkan masalah yang ada di penelitian tersebut. Sedangkan menurut Arikunto (2010: 63), kolaboratif dalam memecahkan permasalahan yang berada dalam penelitian tindakan kelas yaitu adanya kerja sama antara peneliti dan observer untuk mendiskusikan bagaimana cara untuk mengatasi masalah tersebut.

Minat siswa pada pembelajaran siklus II dengan penyajian materi menganalisis cerpen "Guru (1)" karya Putu Wijaya menggunakan model pembelajaran discovery learning dengan menggunakan metode pembacaan cerpen pada vidio yang disajikan kepada siswa SMA Pasundan 1 Cianjur kelas XI IPS 2, sudah mulai meningkat dibandingkan dengan siklus I namun belum memperoleh hasil maksimal karena dari jumlah keseluruhan 24 siswa yang fokus membaca teks cerpen tanpa terganggu oleh temannya sebanyak 15 siswa $(62,4 \%)$.

Minat siswa pada pembelajaran siklus III dengan penyajian materi menganalisis cerpen "Menanti Kematian" karya Jujur prananto menggunakan model pembelajaran discovery learning dengan menggunakan metode ke ruangan yang baru dan nyaman pada siswa SMA Pasundan 1 Cianjur kelas XI IPS 2, sudah tinggi dibandingkan dengan siklus I dan siklus II, dari jumlah kese- luruhan 24 siswa yang fokus membaca teks cerpen tanpa terganggu oleh temannya sebanyak 22 siswa $(91,52 \%)$.

Dari deskripsi keadaan minat siswa di atas dapat disimpulkan dari setiap siklusnya minat siswa mulai meningkat dari siklus I ke siklus II dan ke siklus III, jumlah siswa yang fokus membaca tanpa terganggu oleh temannya pada pembelajaran siklus I 10 siswa $(41,6 \%)$, siklus II 15 siswa $(62,4 \%)$, dan siklus III 22 siswa $(91,52 \%)$. Hal itu membuktikan bahwa model pembelajaran discovery learning dengan menggunakan metode yang berbeda pada setiap siklusnya dalam pembelajaran menganalisis cerpen dapat meningkatkan minat siswa pada pembelajaran sehingga minat siswa menjadi tinggi.

Seperti yang diungkapkan oleh Masitoh (2015: 60), bahwa model discovery learning (penemuan) dapat meningkatkan proses pembelajaran menemukan topik utama paragraf. Hal tersebut terbukti selama pembelajaran, siswa sangat antusias untuk mengikuti pembelajaran. Dapat disimpulkan bahwa dengan model discovery learning (penemuan) dapat meningkatkan minat siswa dalam pembelajaran.

\section{Hasil Belajar Siswa Siklus I, II dan III}

Nilai hasil belajar siswa pada pembelajaran siklus I dengan penyajian materi menganalisis cerpen "Seragam" karya A.K.Basuki menggunakan model pembelajaran discovery learning dengan menggunakan metode internet di blog: http://dirwan darmawangsa.blogspot.co.id/ pada siswa SMA Pasundan 1 Cianjur kelas XI IPS 2, masih rendah karena dari jumlah kesuluruhan 24 siswa, nilai rata-rata yang diperoleh sebesar 69,58 dengan nilai terkecil sebesar 50 $(4,16 \%)$ dan nilai terbesar $85(20,8 \%)$.

Nilai hasil belajar siswa pada pembelajaran siklus II dengan penyajian materi menganalisis cerpen "Guru (1)" karya Putu Wijaya menggunakan model pembelajaran 
discovery learning dengan menggunakan metode menyajikan vidio pembacaan cerpen pada siswa SMA Pasundan 1 Cianjur kelas XI IPS 2, sudah meningkat dari keseluruhan 24 siswa, mendapatkan niai rata-rata 81,66 yang berarti melebihi KKM di sekolah tersebut, namun masih ada siswa yang belum mencapai KKM dengan nilai terendah $60(4,16 \%)$ dan nilai tertinggi $95(8,32 \%)$. Maka peneliti melanjutkan pada siklus III karena target peneliti seluruh siswa harus mencapai KKM.

Nilai hasil belajar siswa pada pembelajaran siklus III dengan penyajian materi menganalisis cerpen "Menanti Kematian" karya Jujur Prananto menggunakan model pembelajaran discovery learning dengan menggunakan metode mencari ruanan baru dan nyaman pada siswa SMA Pasundan 1 Cianjur kelas XI IPS 2, sudah baik dengan memperoleh nilai yang tinggi karena semuanya sudah mencapai KKM, dari jumlah keseluruhan 24 siswa mendapat nilai rata-rata 85,20 dengan nilai terendah $75(8,32 \%)$ dan nilai tertinggi $95(8,32 \%)$. Maka penelitian sudah berhasil.

Dari deskripsi nilai siswa di atas dapat disimpulkan dari setiap siklusnya nilai siswa semakin meningkat dari siklus I ke siklus II dan ke siklus III. Nilai rata-rata dari keseluruhan siswa pada pembelajaran siklus I sebesar 60,58 dan nilai rata-rata pada pembelajaran siklus II sebesar 81,66 dan nilai rata-rata pda siklus III sebesar 85,20. Hal tersebut menunjukan peningkatan yang baik tiap siklusnya dan pada siklus III tidak ada nilai siswa yang di bawah KKM. Jadi pembelajaran menganalisis cerpen menggunakan model pembelajaran discovery learning pada siswa SMA Pasundan 1 Cianjur di kelas XI IPS 2 dapat meningkatkan hasil belajar.

Hal itu sesuai dengan apa yang diungkapkan oleh Budiarty (2015: 174), bahwa model discovery learning yang diterapkan pada siswa SMP Negeri 2 Cianjur kelas VIII-2 dalam pembelajaran menyimak teks biografi dapat meningkatkan hasil belajar siswa, terbukti nilai rata-rata siswa setiap siklusnya mengalami peningkatan dan itu artinya positif.

\section{Analisis Hasil Angket}

Respons siswa terhadap pembelajaran diungkap melalui angket tertutup. Setelah mengikuti pembelajaran menganalisis tokoh dan penokohan pada cerpen menggunakan model pembelajaran discovery learning dengan tujuan mengetahui apa yang dirasakan oleh siswa selama pembelajaran seperti menurut Slameto (2010: 180), indikator yang menunjukan keberhasilan penelitian bisa diekspresikan melalui pernyataan bahwa dia menyukai sesuatu hal, dimanifestasikan melalui partisipasi dalam suatu aktivitas, memberikan perhatian yang lebih besar terhadap subjek teretentu, serta mendapatkan hasil yang optimal mengenai suatu hal tersebut. Berdasarkan angket yang terkumpul pada siklus I, II, dan III diperoleh data tentang respons belajara siswa yang beraneka ragam dan tercermin dalam berbagai aspek seperti berikut ini.

\section{Hasil Angket Berkenaan Keefektifan Belajar Siklus I, II, dan III}

Berdasarkan data pada angket siklus I, II, dan III tiap pernyataan yang berkenaan dengan kefektifan belajar sebagai berikut.

Siklus I dari tiga hasil analisis angket dapat disimpulkan bahwa menggunakan model pembelajaran discovery learning terhadap pembelajaran menganalisis tokoh dan penokohan pada cerpen masih beragam dibuktikan dengan kurang menyenangkan, masih membosankan, dan keadaan kelas kurang kondusif ketika pembelajaran berlangsung.

Siklus II dari tiga hasil analisis angket dapat disimpulkan bahwa menggunakan model pembelajaran discovery learning terhadap pembelajaran menganalisis tokoh dan penokohan pada cerpen mulai menyenangkan, masih membosankan, dan masih kurang kondusif ketika pembelajaran berlangsung. 
Siklus III dari tiga hasil analisis angket dapat disimpulkan bahwa menggunakan model pembelajaran discovery learning terhadap pembelajaran menganalisis tokoh dan penokohan pada cerpen menyenangkan, tidak membosankan, dan menjadi kondusif ketika pembelajaran berlangsung.

Berdasarkan deskripsi di atas dapat disimpulkan bahwa analisis angket berkenaan dengan keefektifan pembelajaran dari yang asalnya siklus I masih beragam dibuktikan dengan kurang menyenangkan, masih membosankan, dan keadaan kelas kurang kondusif ketika pembelajaran berlangsung, pada silus II mulai menyenangkan, masih membosankan, dan masih kurang kondusif ketika pembelajaran berlangsung, dan pada siklus III menyenangkan, tidak membosankan, dan menjadi kondusif ketika pembelajaran berlangsung. Berarti respons siswa terhadap keefektifan pembelajaran mulai terarah ke arah yang lebih baik.

\section{Hasil Angket Berkenaan Minat Belajar Siklus I, II, dan III}

Berdasarkan data pada angket siklus I, II, dan III tiap pernyataan yang berkenaan dengan minat siswa dalam belajar sebagai berikut.

Siklus I dari tiga hasil analisis angket dapat disimpulkan bahwa menggunakan model pembelajaran discovery learning terhadap pembelajaran menganalisis tokoh dan penokohan masih beragam, dibuktikan dengan minat siswa masih kurang, belum tumbuh minat siswa dan kurang berpartisipasi dalam mengerjakan tugas kelompok dan individu, dan kurang memperhatikan pelajaran ketika proses pembelajaran berlangsung.

Siklus II dari tiga hasil analisis angket dapat disimpulkan bahwa menggunakan model pembelajaran discovery learning terhadap pembelajaran menganalisis tokoh dan penokohan mulai menyukai pembelajaran cerpen, mulai tumbuh dan berpartisipasi dalam mengerjakan tugas kelompok dan individu, serta siswa mulai memperhatikan pelajaran ketika proses pembelajaran berlangsung.

Siklus III dari tiga hasil analisis angket dapat disimpulkan bahwa menggunakan model pembelajaran discovery learning terhadap pembelajaran menganalisis tokoh dan penokohan timbul minat siswa dalam pembelajaran cerpen, minat siswa tumbuh dan berpartisipasi dalam mengerjakan tugas kelompok maupun individu, serta memperhatikan guru ketika proses pembelajaran berlangsung.

Berdasarkan deskripsi di atas dapat disimpulkan analisis angket berkenaan dengan minat siswa dalam belajar pada siklus I minat siswa masih kurang, belum tumbuh minat siswa dan kurang berpartisipasi dalam mengerjakan tugas kelompok dan individu, dan kurang memperhatikan pelajaran ketika proses pembelajaran berlangsung, pada siklus II mulai menyukai pembelajaran cerpen, mulai tumbuh dan berpartisipasi dalam mengerjakan tugas kelompok dan individu, serta siswa mulai memperhatikan pelajaran ketika proses pembelajaran berlangsung, dan pada siklus III minat siswa tumbuh dan berpartisipasi dalam mengerjakan tugas kelompok maupun individu, serta memperhatikan guru ketika proses pembelajaran berlangsung. Jadi minat siswa dari setiap siklusnya berdasarkan angket ternyata semakin baik dan meningkat.

\section{Hasil Angket Berkenaan Hasil Belajar Siklus I, II, dan III}

Berdasarkan data pada tiap pernyataan yang berkenaan dengan hasil belajar siswa pada siklus I, II, dan III sebagai berikut.

Siklus I dari empat hasil analisis angket dapat disimpulkan bahwa menggunakan model pembelajaran discovery learning terhadap pembelajaran menganalisis tokoh dan penokohan masih beragam, dibuktikan dengan siswa masih kesulitan dalam mencari tokoh 
dan penokohan, membuat siswa masih kesulitan dalam memahami cerpen dan mereka yakin nilainya akan turun setelah guru menggunakan model pembelajaran discovery learning selama proses pembelajaran berlangsung.

Siklus II dari empat hasil analisis angket dapat disimpulkan bahwa menggunakan model pembelajaran discovery learning terhadap pembelajaran menganalisis tokoh dan penokohan tidak kesulitan dalam mencari tokoh dan penokohan, mudah dalam mencari tokoh dan penokohan, mudah dalam memahami cerpen, dan tidak yakin nilai mereka akan turun setelah guru menggunakan model pembelajaran discovery learning selama proses pembelajaran berlangsung.

Siklus III dari empat hasil analisis angket dapat disimpulkan bahwa menggunakan model pembelajaran discovery learning terhadap pembelajaran menganalisis tokoh dan penokohan tidak kesulitan dalam mencari tokoh dan penokohan, mudah dalam mencari tokoh dan penokohan, mudah dalam memahami cerpen, dan tidak yakin bahwa nilai mereka akan turun setelah guru menggunakan model pembelajaran discovery learning selama proses pembelajaran berlangsung.

Berdasarkan deskripsi di atas angket yang berhubungan dengan hasil belajar dapat ditarik simpulan siklus I membuat siswa masih kesulitan dalam memahami cerpen dan mereka yakin nilainya akan turun setelah guru menggunakan model pembelajaran discovery learning selama proses pembelajaran berlangsung, pada siklus II mudah dalam memahami cerpen, dan tidak yakin nilai mereka akan turun setelah guru menggunakan model pembelajaran discovery learning selama proses pembelajaran berlangsung, dan pada siklus III mudah dalam memahami cerpen, dan tidak yakin bahwa nilai mereka akan turun setelah guru menggunakan model pembelajaran discovery learning selama proses pembelajaran berlangsung. Jadi dari setiap siklus memiliki perubahan yang positif yang menjadikan respons siswa semakin baik terhadap pembelajaran cerpen menggunakan model pembelajaran discovery learning pada siswa SMA Pasundan 1 Cianjur di kelas XI IPS 2.

Hal itu sesuai dengan apa yang diungkapkan oleh Budiarti (2015: 175), bahwa respons siswa terhadap pembelajaran menyimak teks biografi pun dengan menggunakan model discovery learning hasilnya positif.

\section{SIMPULAN}

Berdasarkan hasil pengumpulan dan pengolahan data menggunakan model pembelajaran discovery learning dalam pembelajaran menganalisis tokoh dan penokohan pada cerita pendek di kelas XI SMA Pasundan 1 Cianjur tahun 2016-2017 disimpulkan hal-hal sebagai berikut.

Keadaan keefektifan kelas dapat disimpulkan bahwa dari setiap siklusnya ada peningkatan ke arah positif sebab dari siklus I ke siklus II dan dari siklus II ke siklus III jumlah siswa yang fokus pada pembelajaran semakin bertambah. Jadi kegiatan tindakan kelas sudah berhasil dan berhenti sampai di siklus III dengan menggunakan model pembelajaran discovery learning dapat meningkatkan keefektifan pembelajaran.

Minat siswa dalam belajar mengalami peningkatan, ini terbukti dari jumlah siswa yang fokus membaca, dari siklus I ke siklus II dan dari siklus II ke siklus III semakin bertambah dan meningkat. Maka dari itu, dapat disimpulkan bahwa kegiatan tindakan kelas sudah berhasil dan berhenti sampai di siklus III dengan menggunakan model pembelajaran discovery learning dapat meningkatkan minat siswa dalam membaca secara fokus tanpa terganggu.

Hasil belajar siswa dengan menggunakan model pembelajaran dicovery learning dapat meningkatkan hasil belajar siswa dalam menganalisis tokoh dan penokohan pada cerpen karena hasil belajar siswa setiap 
siklusnya meningkat. Pada siklus I nilai ratarata siswa sebesar 69,58 lalu pada siklus II nilai siswa meningkat menjadi 81,66 namun masih ada 3 orang yang memperoleh nilai di bawah KKM maka dilanjutkan pada siklus III meningkat menjadi 85,20 serta seluruh siswa nilainya sudah mencapai KKM. Maka proses tindakan kelas sudah berhasil dan berhenti sampai di siklus III.

Sehubungan dengan kesimpulan di atas, disajikan saran-saran kiranya dapat memberikan masukan dalam pengembangan pembelajaran menganalisis tokoh dan penokohan pada cerpen dengan model pembelajaran discovery learning.

Model pembelajaran dicovery learning cocok diterapkan pada pembelajaran menganalisis tokoh dan penokohan pada cerpen karena dapat membuat keadaan kelas menjadi efektif, minat siswa menjadi tinggi dan hasil belajar siswa menjadi tinggi.

Siswa harus sering membaca berbagai macam cerpen supaya tingkat pemahaman mereka lebih tinggi terhadap cerpen dan mengetahui tokoh dan penokohan yang terkandung di dalamnya.

Untuk peneliti yang lain yang sebentar lagi akan menjadi pengajar, penelitian tindakan kelas dapat dikembangkan dalam pelaksanaan pembelajaran setelah menjadi seorang pengajar sebab tujuan penelitian tindakan kelas yaitu untuk meningkatkan sesuatu hal yang bermasalah dilingkungan pembelajaran.

\section{DAFTAR PUSTAKA}

Aqib, Zainal. 2007. Penelitian Tindakan Kelas Untuk Guru. Bandung: Yrama x.

Arikunto, Suharsimi. 2010. Prosedur Penelitian Suatu Pendekatan Praktik. Jakarta: Rineka Cipta.

dkk. 2012. Penelitian Tindakan Kelas. Jakarta: Bumi Aksara.

Budiarty, Resty Rahayu. 2015. "Peningkatan Kemampuan Menyimak Teks Biografi Tokoh Nasional Menggunakan Model Discovery Learning pada Siswa Kelas VIII SMP Negeri 2 Cianjur Tahun Ajar 2014-2015”. Skripsi: FKIP UNSUR Cianjur. (Tidak Dipublikasikan).

Hosnan. 2014. Pendekatan Saintifik dan Kontekstual dalam Pembelajaran Abad 21. Bogor: Ghalia Indonesia.

Masitoh, Ai. 2015. "Meningkatkan Kemampuan Siswa dalam Menentukan Topik Utama Paragraf Memalui Model Pembelajaran Penemuan Kelas VIII SMP 6 Sukanagara Kabupaten Cianjur Tahun Ajar 2014-2015”. Skripsi: FKIP UNSUR Cianjur. (Tidak Dipublikasikan).

Ristiani, Iis. 2012. Kajian dan Apresiasi Puisi \& Prosa. Yogyakarta: Aswaja Pressindo.

Slameto. 2010. Belajar dan Faktor-faktor yang Mempengaruhi. Jakarta: Rineka Cipta.

Tarigan, Henry Guntur. 2011. Prinsip-prinsip Dasar Sastra. Bandung: Angkasa. 1994. Menulis Sebagai Suatu Keterampilan Berbahasa. Bandung: Angkasa. 